\title{
Newcastle Disease in Local Chickens of Live Bird Markets and Households in Zamfara State, Nigeria
}

\author{
A. H. Jibril, ${ }^{1}$ J. U. Umoh, ${ }^{2}$ J. Kabir, ${ }^{2}$ L. Saidu, ${ }^{3}$ A. A. Magaji, ${ }^{1}$ M. B. Bello, ${ }^{1}$ and A. A. Raji ${ }^{1}$ \\ ${ }^{1}$ Department of Veterinary Physiology, Faculty of Veterinary Medicine, Usmanu Danfodiyo University, Sokoto P.M. B 2346, Nigeria \\ ${ }^{2}$ Department of Veterinary Public Health and Preventive Medicine, Ahmadu Bello University, Zaria, Nigeria \\ ${ }^{3}$ Ahmadu Bello University Veterinary Teaching Hospital, Zaria, Nigeria
}

Correspondence should be addressed to A. H. Jibril; jibrilah50@yahoo.com

Received 30 November 2013; Accepted 18 December 2013; Published 16 January 2014

Academic Editors: Q. Chen and M. Lancellotti

Copyright (C) 2014 A. H. Jibril et al. This is an open access article distributed under the Creative Commons Attribution License, which permits unrestricted use, distribution, and reproduction in any medium, provided the original work is properly cited.

\begin{abstract}
Newcastle disease constitutes a major constraint to rural poultry production system in Nigeria. This study used serological method to estimate the level of circulating antibodies against ND in nonvaccinated village chickens, raised under traditional management system in Zamfara State, Nigeria. Competitive Enzyme Linked Immunosorbent Assay was used to analyze 504 chicken sera for Newcastle disease virus antibodies from randomly selected households and live bird markets. Higher seroprevalence rate of Newcastle disease virus antibodies was detected in both household and live bird markets. Overall, seropositive rate was found to be $32.5 \%$ (164/504). About 35.8\% (115/321) sero-positive rate was obtained from live bird markets while 26.8\% (49/183) seropositive rate was found in households. Comparison was made between the sero prevalence of house hold and live bird markets as well as between sexes. Live bird markets show a statistically significant higher prevalence rate $(P<0.05)$ when compared with chickens sampled from households (OR 1.53; 95\% CI, 1.024-2.275). The prevalence of ND indicated the presence of the virus amongst the population, and hence there should be an improvement in the vaccine campaign against ND for rural poultry especially the use of thermostable vaccine to reduce the chances of vaccine failure.
\end{abstract}

\section{Introduction}

Newcastle disease (ND) is a major viral disease of economic importance in poultry [1] and rated as one of the greatest constraints to the development of rural poultry production in Nigeria and in most developing countries, causing serious threats [2]. All ages of different species of birds are susceptible to ND, although being substantially less with advancement to maturity [3]. The acute and virulent form may result in $90 \%$ mortality or more in affected flocks [4]. It is an acute, rapidly spreading, contagious, nervous and respiratory disease of birds of all ages [5]. The clinical signs of ND are known to vary based on the virulence and tropism of the ND virus involved, species of the bird, age of the host, immune status, and environmental condition [6].

Nigeria poultry population is estimated to be 137.6 million, with backyard poultry population constituting $84 \%$ (115.8 million) and 16\% (21.7 million) of exotic poultry, with a higher percentage of this poultry raised for subsistence production [7]. Village poultry production provides an important source of high quality protein, is reserved for times of celebrations, and is a good source of income for rural families [8]. This category of birds represents a significant part of the Nigerian rural economy in particular and of the national economy as a whole and is kept under the extensive management system [9]. The resources derivable from the chickens cannot be fully utilized unless the disease is controlled particularly in the village poultry flocks that are believed to keep the virus in circulation and act as reservoirs and carriers to themselves and the more susceptible exotic breeds in commercial farms [10].

\section{Materials and Methods}

2.1. Study Area. The study was carried out in six local governments (Bungudu, Gusau, Talata-Mafara, Bakura, KauraNamoda, and Zurmi) of Zamfara State, Nigeria. Zamfara State is located between latitudes $10^{\circ} 50 \mathrm{~N}$ and $13^{\circ} 58 \mathrm{~N}$ and 
TABLE 1: Prevalence of Newcastle disease from selected local governments of Zamfara State.

\begin{tabular}{|c|c|c|c|c|c|}
\hline $\mathrm{S} / \mathrm{N}$ & Local governments & Number of samples & Number of positives & Number of negatives & Prevalence (\%) \\
\hline 1 & Gusau & 100 & 56 & 44 & 56.0 \\
\hline 2 & Bungudu & 70 & 34 & 36 & 48.5 \\
\hline 3 & Zurmi & 75 & 26 & 49 & 34.7 \\
\hline 4 & Kaura-Namoda & 99 & 14 & 85 & 14.1 \\
\hline 5 & Bakura & 70 & 12 & 58 & 17.1 \\
\hline \multirow[t]{2}{*}{6} & Talata-Mafara & 90 & 22 & 68 & 24.4 \\
\hline & Total & 504 & 164 & 340 & 32.5 \\
\hline
\end{tabular}

Chi-square value $=58.94$.

$P$ value $=0.001$

TABle 2: Prevalence of Newcastle based on location in Zamfara State.

\begin{tabular}{|c|c|c|c|c|c|c|c|}
\hline $\mathrm{S} / \mathrm{N}$ & Location & Number of samples & Number of positives & Number of negatives & Prevalence (\%) & Odds ratio & $95 \% \mathrm{CI}$ \\
\hline 1 & LB markets & 321 & 115 & 206 & 35.8 & $1.53^{*}$ & \multirow{2}{*}{$1.024-2.275$} \\
\hline 2 & Households & 183 & 49 & 134 & 26.8 & 1.00 & \\
\hline & Total & 504 & 164 & 340 & 32.5 & & \\
\hline
\end{tabular}

Chi-square value $=3.946$.

$P$ value $=0.0470$.

${ }^{*}$ Statistical significance between variables when using odd ratio.

longitudes $4^{\circ} 16 \mathrm{E}$ and $7^{\circ} 13 \mathrm{E}$. It has a warm tropical climate between March and May. The vegetation of the state consists of Sudan and Northern Guinea Savannah. It has a total human population of $3,278,873$ [11] and an estimated poultry population of 5845,508 [7]. The state has 14 local governments and has 3 senatorial districts.

2.2. Sera Collection. Multistage sampling procedure was applied to divide the state into three stages corresponding to three senatorial districts. Two local governments were then randomly selected from each district, making a total number of six local governments that were considered in this study. A total of 504 sera samples were collected from live bird markets and households from all the six selected local governments across the state. Two milliliter of chicken blood was collected through the brachial vein using a 21-gauge sterile hypodermic needle and $2 \mathrm{~mL}$ syringes. The syringes were labeled and kept in slanting position till clot formation. Sera were harvested, transferred into a sterile serum bottles, and stored at $-20^{\circ} \mathrm{C}$. All sera at the end of the sampling were taken to the viral zoonosis laboratory of the Department of Veterinary Public Health and Preventive Medicine, Ahmadu Bello University, Zaria, for serology.

2.3. Serology. Competitive ELISA diagnostic kit was obtained from ID Vet, Innovative Diagnostics, France. The kit procedure is based on blocking Enzyme Linked Immunosorbent Assay. $100 \mu \mathrm{L}$ of positive control was added to positive control wells A1 and $\mathrm{B} 1$ and $100 \mu \mathrm{L}$ of negative control to negative control wells $\mathrm{C} 1$ and D1 using micropipette. $80 \mu \mathrm{L}$ of dilution buffer 2 was added to each of the wells. Using multichannel pipette, $20 \mu \mathrm{L}$ of undiluted serum was then added to the remaining selected wells and mixed thoroughly with the buffer. The plates were then sealed and incubated at room temperature for 30 minutes. Anti-NDV conjugate $10 \mathrm{x}$ was prepared by diluting anti-NDV-HRP conjugate to $1 / 10$ dilution buffer 5 . After incubation the plates were washed 3 times with wash solution. Using multichannel pipette, $100 \mu \mathrm{L}$ of anti-NDV conjugate $1 \mathrm{x}$ was added to each well. The plates were rinsed three times with wash solution. $100 \mu \mathrm{L}$ of the substrate solution was added to each well. And this was incubated at room temperature for ten minutes in the dark. The reaction was stopped by adding $50 \mu \mathrm{L}$ of stop solution to each well which is mixed thoroughly. Optical density was read at $450 \mathrm{~nm}$ by using microplate reader.

2.4. Data Analysis. The data obtained was subjected to SPSS package version 16 . Categorical variables (sex, location) were evaluated using Chi-square to check for independence, and odds ratio at $95 \%$ confidence interval was used to measure the strength of association between variables and prevalence of Newcastle disease. Values of $P<0.05$ were considered significant.

\section{Results}

The overall seroprevalence of Newcastle disease in the study area was $32.5 \%$. The highest prevalence was found in Gusau local governments $(56.0 \%)$ while the least was detected in Kaura-Namoda local governments (14.1\%) (Table 1). Table 2 indicates that chickens from live bird markets show a higher prevalence rate $(35.8 \%)$ when compared to those sampled from households (26.8\%). Prevalence of $35.7 \%$ was recorded in male chickens while $28.9 \%$ was obtained from female chickens as indicated in Table 3. 
TABLE 3: Sex-specific prevalence of Newcastle disease in Zamfara State.

\begin{tabular}{lccccccc}
\hline S/N & Sex & Number of samples & Number of positives & Number of negatives & Prevalence (\%) & Odds ratio & 95\% CI \\
\hline 1 & Male & 272 & 97 & 175 & 35.7 & 1.37 & $0.936-1.990$ \\
2 & Female & 232 & 67 & 165 & 28.9 & 1.0 & \\
\hline
\end{tabular}

Chi-square value $=2.324$.

$P$ value $=0.1274$.

\section{Discussion}

The present serological study revealed the presence of circulating antibodies of Newcastle disease among sampled village chickens from selected local governments of Zamfara State. An overall seroprevalence of $32.5 \%$ from the six local governments of Zamfara State is an indication of endemicity. Antibodies detected may be a result of natural infection since vaccination of the village poultry is rarely undertaken in Nigeria [12]. In similar studies, [13] reported a variable sero prevalence of $25-81.5 \%$ in Tanzania, in Ethiopia, $43.68 \%$ seropositive rate of NDV was reported in the cool central highlands [14] while [15] reported 19.78\%, [16] reported $14 \%$ sero prevalence in non-vaccinated village chickens in Niger. Reference [17] reported a prevalence of $63 \%$ in south eastern Nigeria. Reference [18] reported a prevalence of $46 \%$ in village chickens in Borno State and [19] reported an ND prevalence of $54.67 \%$ in Nasarawa State. This finding of NDV sero prevalence in these apparently healthy birds suggests that the birds have either recovered from clinical ND or are having subclinical infections [20]. A similar study was conducted in Ibadan using indirect ELISA and an overall prevalence rate of $73.3 \%$ was obtained [21]. Although there is a statistically significant $(P<0.05)$ higher prevalence in Gusau compared to other local government areas (LGAs), the higher circulating antibodies in Gusau may be due to higher concentration of live bird markets in this LGA. The lower prevalence rate in Bakura, Talata-Mafara, and KauraNamoda may be due to vaccination activities of commercial poultry that may contribute to mild infection due to the spread of vaccine virus to local birds through commercial poultry workers [19].

Live bird markets show a statistically significant higher prevalence rate $(P<0.05)$ when compared with chickens sampled from households (OR 1.53; 95\% CI, 1.024-2.275). This may be due to the fact that live bird markets contribute to the persistence and spread of ND virus. These birds are exposed to birds from multiple sources having a higher tendency of circulating the virus and may serve as a source of infection to house hold chickens when introduced [22] Similar studies conducted by [23] show $25.5 \%$ prevalence in live bird markets of Kogi State, Nigeria.

This study also shows a higher prevalence rate among the male chickens. It was however observed that this difference is statistically insignificant $(P>0.05)$. In a similar study conducted by [15] in Ethiopia, ND shows a higher prevalence rate among males $(21.74 \%)$ than among females (19.16\%). However, a slightly higher prevalence of $32.63 \%$ among female chickens was obtained by [24] when compared with a prevalence of 31.63 among male chickens.

\section{Acknowledgments}

The authors would like to thank all the farmers that allowed them to take samples from their chickens and to all staff of the department of Veterinary Public Health and Preventive Medicine, Ahmadu Bello University, for their technical support.

\section{Conflict of Interests}

There is no competing interest whatsoever that could have influenced the results of this study in any manner.

\section{References}

[1] G. N. Anosa and D. F. Adene, "Comparative tissue reactivity of lentogenic strains of Newcastle disease vaccines in Nigeria," Nigerian Veterinary Journal, vol. 28, no. 3, pp. 6-10, 2007.

[2] S. B. Oladele, P. Abdu, K. A. N. Esievo, A. J. Nok, and N. M. Useh, "Prevalence of Newcastle disease virus antibodies in chickens reared in Zaria," in Proceedings of the 28th Annual Conference of Nigerian Society of Animal Production, vol. 28, pp. 7-9, 2003.

[3] F. R. Beaudette, "A review of literature on Newcastle disease," in Proceedings of the 4th Annual Meeting US Livestock Association, vol. 47, pp. 122-177, 1943.

[4] D. J. Alexander and W. H. Allan, "Newcastle disease virus pathotypes," Avian Pathology, vol. 3, pp. 269-278, 1974.

[5] E. N. Okeke and A. G. Lamorde, "Newcastle disease and its control in Nigeria," in Viral Disease of Animals in Africa, A. Olufemi Williams and W. N. Masiga, Eds., CTA/OAU/STRC/ Publication, Lagos, Nigeria, 1988.

[6] R. Alders and P. B. Spradbrow, Controlling Newcastle Disease in Village Chickens, Monograph Australian Center for International Resources, Canberra, Australia, 2002.

[7] Federal Ministry of Agriculture and Rural Development, Federal Department of Livestock and Pest Control Services, Highly Pathogenic Avian Influenza Standard Operating Procedures, February 2006.

[8] M. B. Abubakar, A. D. El-yuguda, A. A. Yerima, and S. S. Baba, "Seroprevalence of active and passive immunity against egg drop syndrome 1976 (EDS 76) in village poultry in Nigeria," Asian Journal of Poultry Science, vol. 2, pp. 58-61, 2008.

[9] M. K. Ajala, B. I. Nwagu, and C. U. Osuhor, "Socio-economic of free-range guinea fowl production among agro-pastoral Fulani women in Giwa L.G.A of Kaduna state, Nigeria," International Journal of Tropical Agriculture, vol. 15, pp. 37-44, 1997.

[10] A. O. Olabode, A. G. Lamorde, N. N. Shidali, and A. A. Chukwuedo, "Village chickens and Newcastle disease in Nigeria," Australian Centre For International Agricultural Research Proceedings, no. 39, pp. 159-160, 1992.

[11] National Population Commission, "Social Statistic in Nigeria," Beaureu of Statistics, Lagos, Nigeria, p. 300, 2009. 
[12] P. A. Abdu, S. U. Abdullahi, A. A. Adesiyun, and C. D. Ezeokoli, "Challenge study on infectious bursal disease in chicks derived from vaccinated hens," Tropical Animal Health and Production, vol. 19, no. 1, pp. 47-52, 1987.

[13] M. G. S. Yongolo, Epidemiology of Newcastle disease in village chickens in Tanzania [M.S. thesis], Sokoine University of Agriculture, Morogoro, Tanzania, 1996.

[14] H. Ashenafi, Survey on identification of major diseases of local chickens in three selected agroclimatic zones in central Ethiopia [M.S. thesis], Faculty of Veterinary Medicine, Addis Ababa University, Debre Zeit, Ethiopia, 2000.

[15] Z. Aschalew, S. Teshale, G. Esayas, and A. Gelegay, "Newcastle disease in village chickens in the southern and rift valley districts in Ethiopia," International Journal of Poultry Science, vol. 4, no. 7, pp. 507-510, 2005.

[16] C. Courtecuisse, F. Japiot, N. Bloch, and I. Diallo, "Serological survey on Newcastle and Gumboro diseases, pasteurellosis and pullorosis in local hens in Niger," Revue d'Elevage et de Médecine Vétérinaire des pays Tropicaux, vol. 43, no. 1, pp. 27-29, 1990.

[17] L. J. E. Orakaja, D. F. Adene, B. M. Anene, and E. A. Onuoha, "Seroprevalence of Newcastle disease in local chickens from south east derived Savannah zone of Nigeria," Revue d'Elevage et de Médecine Vétérinaire des pays Tropicaux, vol. 52, pp. 185-188, 1999.

[18] A. D. EL-Yuguda, I. S. Ngulde, M. B. Abubakar, and S. S. Baba, "Village chicken health, management and production indices in selected villages of Borno State," Nigeria Family Poultry Journal, vol. 17, no. 1-2, 2007.

[19] A. E. Salihu, A. A. Chukwuedo, G. O. N. Echeonwu et al., "Seroprevalence of Newcastle disease virus infection in rural household birds in Lafia, Akwanga and Keffi Metropolis, Nasarawa State Nigeria," International Journal of Agricultural Sciences, vol. 2, no. 2, pp. 109-112, 2012.

[20] J. G. Bell and S. Mouloudi, "A reservoir of virulent Newcastle disease virus in village chicken flocks," Preventive Veterinary Medicine, vol. 6, no. 1, pp. 37-42, 1988.

[21] O. G. Ohore, P. C. Ozegbe, B. O. Emikpe, and V. E. Okojie, "Survey of antibodies to Newcastle disease virus in apparently healthy adult Nigeria indigenous chickens (Gallus domesticus) in Ibadan using ELISA," African Journal of Clinical and Experimental Microbiology, vol. 3, no. 1, pp. 38-40, 2002.

[22] M. L. Killian, "National veterinary services laboratories avian influenza and Newcastle disease diagnostics report," in Proceedings of the 113th Annual Meeting of the United States Animal Health Association, pp. 590-593, 2009.

[23] O. N. Ameji, P. A. Abdu, and L. Saidu, "Seroprevalence of Avian influenza, Newcastle disease and Gumboro disease in chicken in Kogi State, Nigeria," Bulletin of Animal Health and Production African Journal, vol. 59, no. 4, 2011.

[24] T. Sarkelm, A. Hagos, and A. Zeleke, "Seroprevalence study of Newcastle disease in local chickens in central Ethiopia," International Journal of Applied Research in Veterinary Medicine, vol. 3, no. 1, pp. 25-29, 2005. 


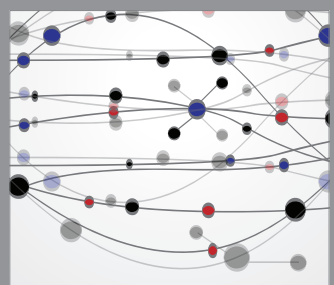

The Scientific World Journal
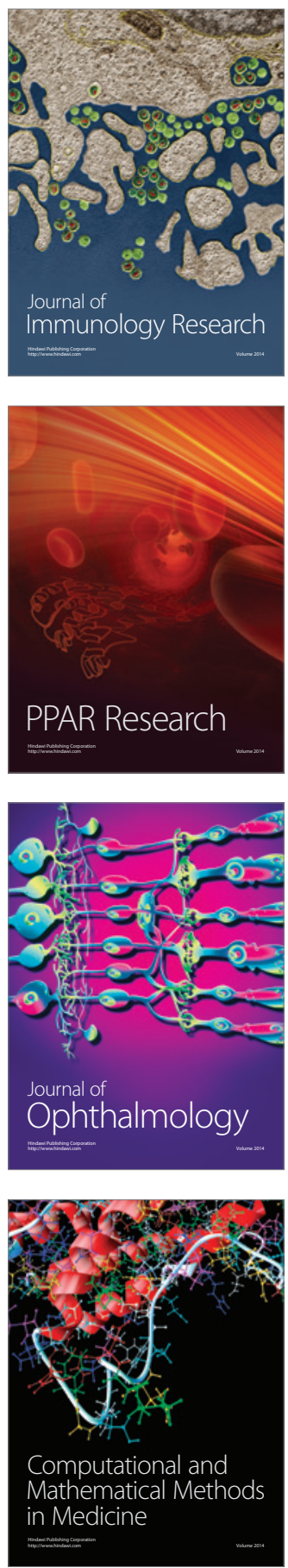

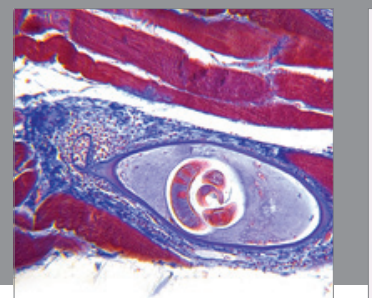

Gastroenterology

Research and Practice
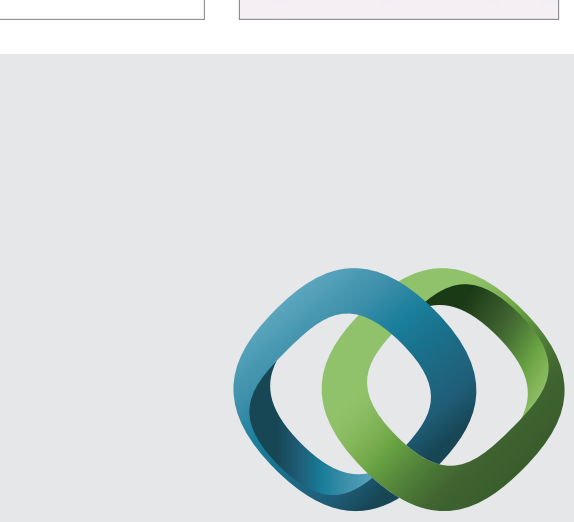

\section{Hindawi}

Submit your manuscripts at

http://www.hindawi.com
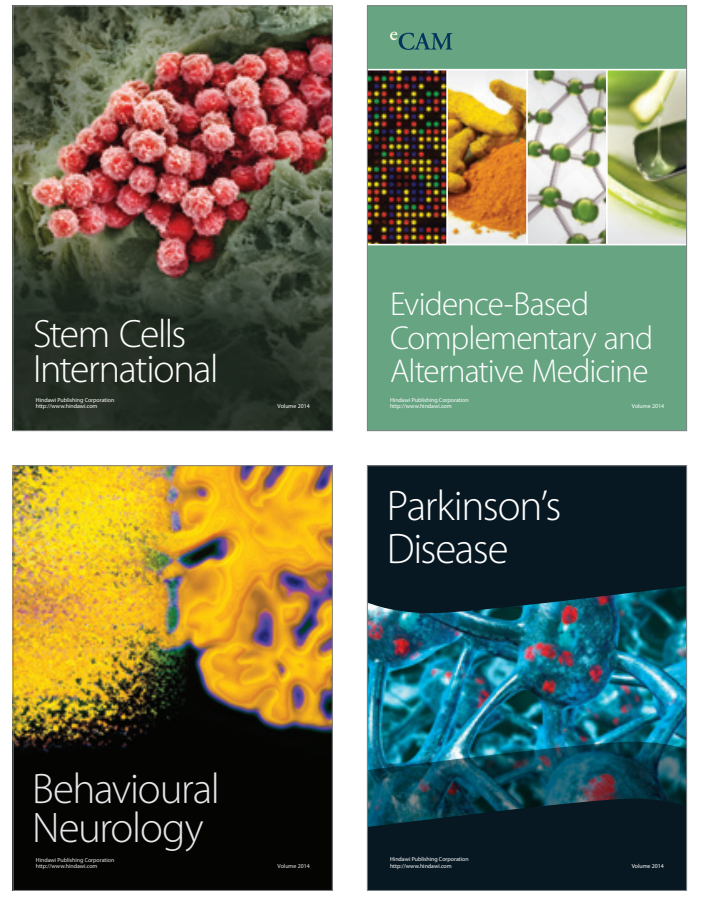
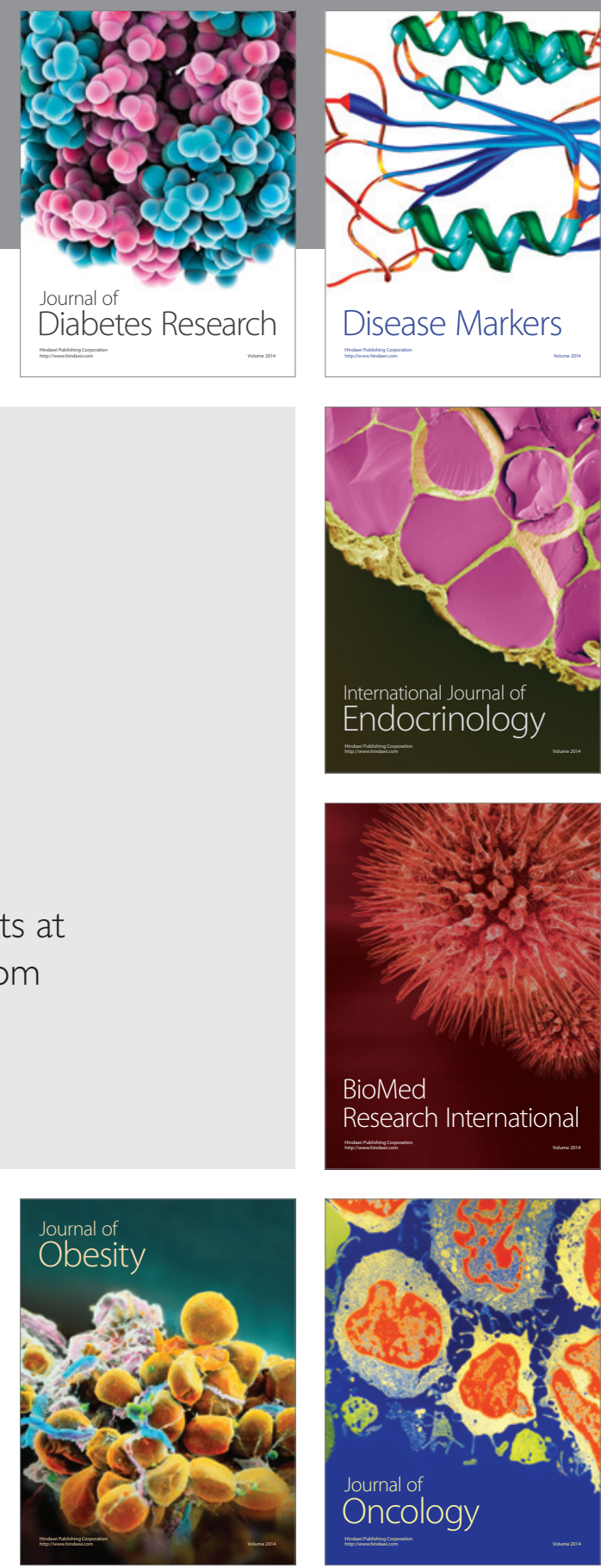

Disease Markers
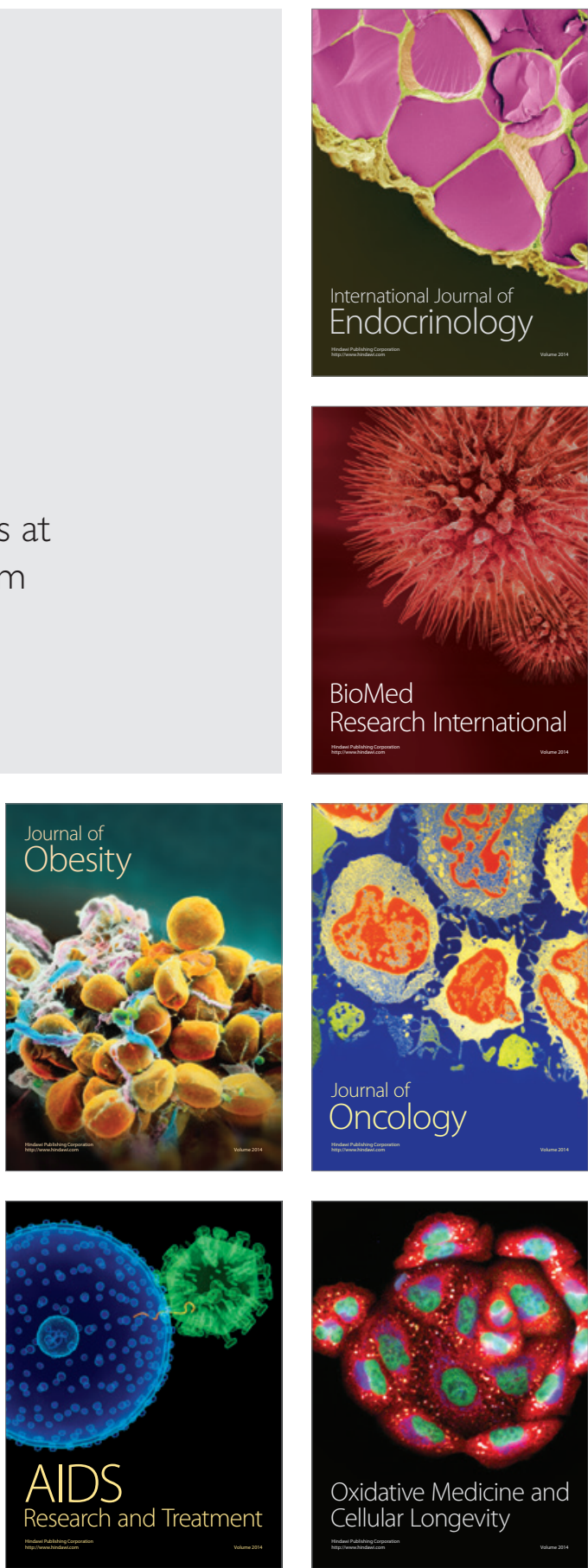